\title{
Neorotalia omanensis and Operculina musawaensis from the Sultanate of Oman
}

\author{
Abdul Razak Siddiq Al-Sayigh \\ Department of Earth Sciences, College of Science, Sultan Qaboos University, P.O. Box 36, Al- \\ Khoud, 123 Muscat, Sultanate of Oman, Email: alsayigh@squ.edu.om.
}

\begin{abstract}
Two new species of larger benthic foraminifera, Neorotalia omanensis n. sp. and Operculina musawaensis n. sp. are described and illustrated from the eastern Oman Mountains. $N$. omanensis n. sp. occurs in the Musawa Formation in association with the planktonic foraminifera Morozovella edgari and Truncarotaloides topilensis indicating an early to middle Eocene age (P10P13). Operculina musawaensis n. sp. occurs in the Abat Formation in association with the planktonic foraminifera Acarinina esnaensis and A. soldadensis indicating an early Eocene age (P6). This is the first known record showing the presence of genus Neorotalia in the Middle East. Representatives of the larger foraminiferal genus Linderina sp. are also described and illustrated from the Musawa Formation and compared with the published Linderina species in the surrounding countries.
\end{abstract}

Keywords: Neorotalia omanensis; Operculina musawaensis; Abat Formation; Musawa Formation; Oman.

نوعين جديدين من نيوروتاليا عمانينسس وابركيولينا موساواينس من سلطنة عمان مع ملاحظات على تصنيف الندرينا

عبدالرزاق صديق الصايغ

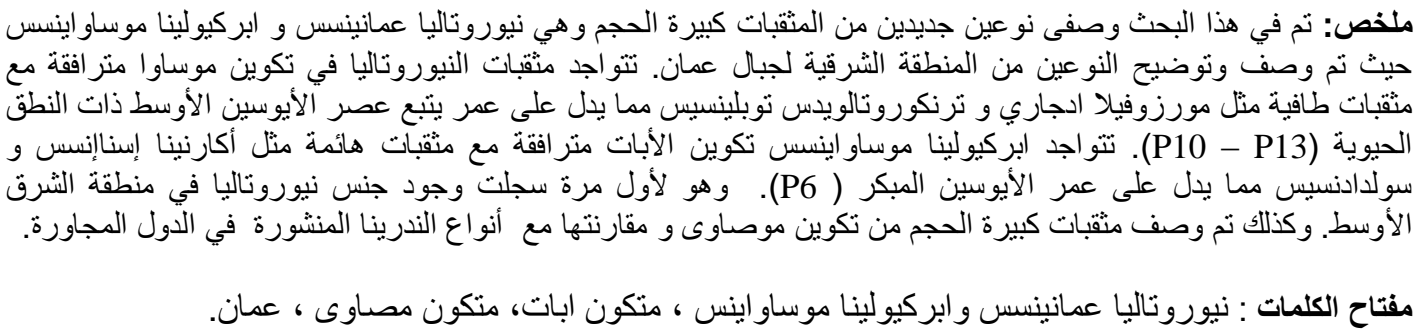

\section{Introduction}

$\mathbf{T}$ he genus Neorotalia sp. is poorly known from Arabia. The only published record from the northern Oman Mountains is Linderina rajasthanensis (Singh, 1953), found by White (1989) in Wadi Rusayl. White (1989) synonymized all four of Singh's (1953) species (rajasthanensis, bikanerensis, kolayatensis, kirtharensis) under one name (rajasthanensis) stating that test size, and shape (globular to discoidal with central boss, depending on the amount of lateral thickening) are insignificant as the means of discriminating species. The geographic distribution of the recorded species is very broad, including southern Europe (England to Romania), the Middle East, the Indian Sub-continent, Indonesia, Australia, Western Pacific and the Caribbean, possibly reflecting the presence of different genera with similar features (Ferrandex-Canadell and Serr-Kiel, 1999). In this paper the author reports two new species of large foraminifera in the Abat and Musawa Formations in the eastern part of the northern Oman Mountains. 


\section{Geological Setting}

The section studied is located in the Jabal Ja'alan area of the Sharqiyah region, in the foothills of the eastern Oman Mountains, north Oman (Figure 1). The samples studied were collected from the Abat and Musawa Formations outcropping along the southern side of Wadi Musawa (Figure 1). Here a $1220 \mathrm{~m}$ thick mixed clastic-carbonate succession of Tertiary age rests unconformably on an older granitic basement. The Tertiary strata comprise, from bottom to top, the Abat, Musawa and Tahwah Formations (Figure 2). The samples yielding the new taxa described herein were collected from unit D of the Abat Formation and Unit H of the Musawa Formation (Figure 2). The Abat Formation comprises interbedded marine limestone (mudstone to packstone) and shale. The Musawa Formation contains three fluvial units, each of which is ferruginous towards its base and contains coal towards its top. The fluvial units are overlain by marine limestone and shale. The Abat Formation is Late Palaeocene to Early Eocene and the Musawa Formation is Early to Late Eocene based on planktonic foraminiferal assemblages. Previous work in the area was mainly focused on geological mapping (Villey et al., 1986; Filbrandt et al., 1990; Roger et al., 1991). Although Villey et al. (1986) include micropalaeontological data, these data are limited to faunal lists and broad age assignments and do not include illustrations and descriptions of the taxa recorded.

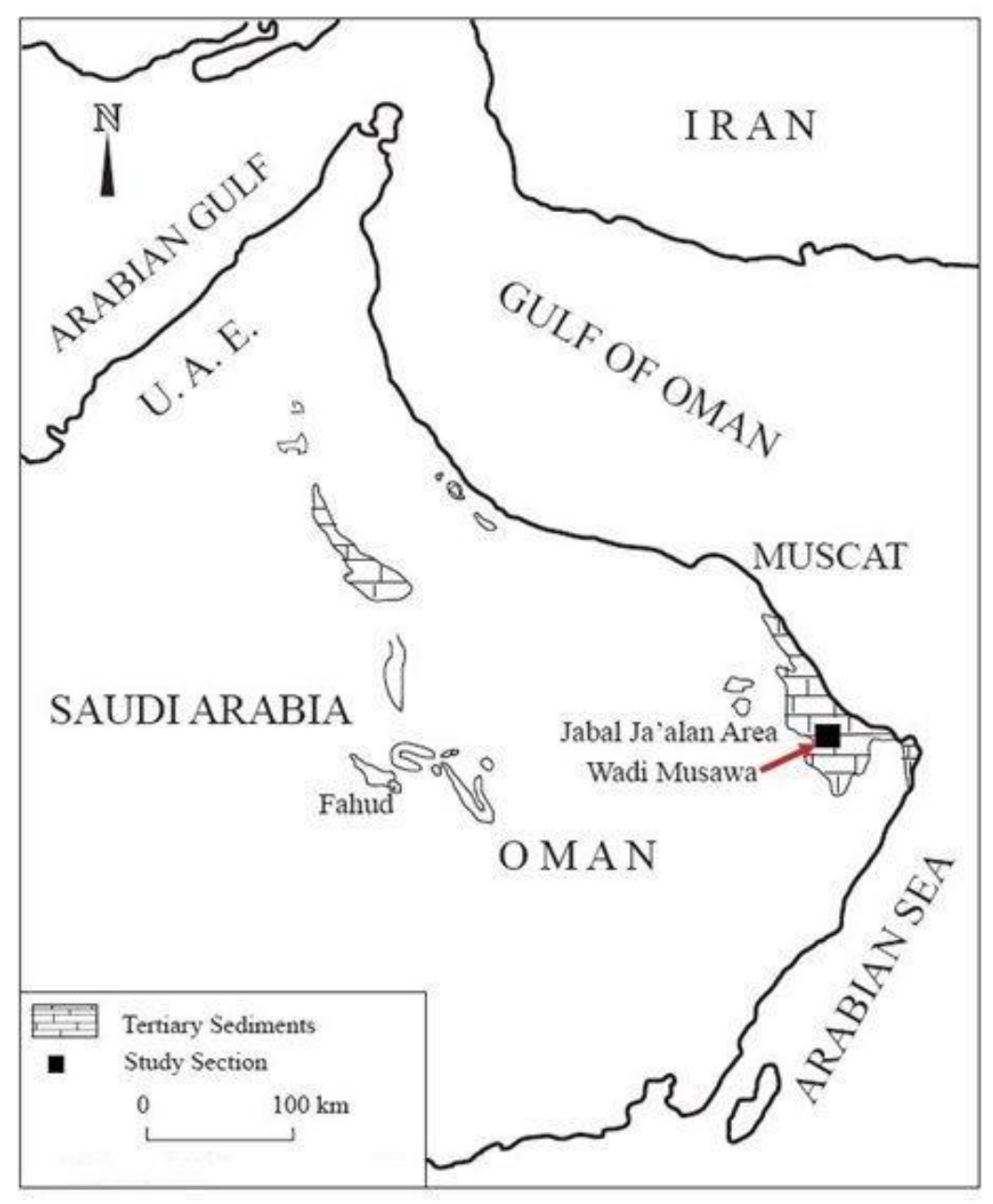

Figure 1. Location map of the study area (modified after Montenat et al., 1977).

\section{Lithostratigraphy}

This section describes the lithostratigraphic units containing the microfossils reported in the present study.

\section{Abat Formation}

Type-Locality: Wadi Musawa - Latitude $22^{\circ} 19^{\prime} \mathrm{N}$ and Longitude $58^{0} 23^{\prime} \mathrm{E}$

This unit unconformably overlies Maastrichtian sandstone turbidite and marl of the Fayah Formation, and is conformably overlain by sandstone of the Musawa Formation within which it interdigitates in its upper part. The lower part of the Abat Formation consists of thinly interbedded shale and mudstone overlain by planktonic foraminiferabearing wackestone with interbeds of mudstone and calcarenite. These beds pass upwards (across a 9 m unexposed section) into resedimented wackestone and packstone comprising six depositional cycles. The middle part of the Abat 


\section{NEOROTALIA OMANENSIS and OPERCULINA MUSAWAENSIS}

Formation is characterized by thinly bedded wackestone overlain by shale and followed by an upper unit of limestone and dolomite capped by a palaeosol horizon.

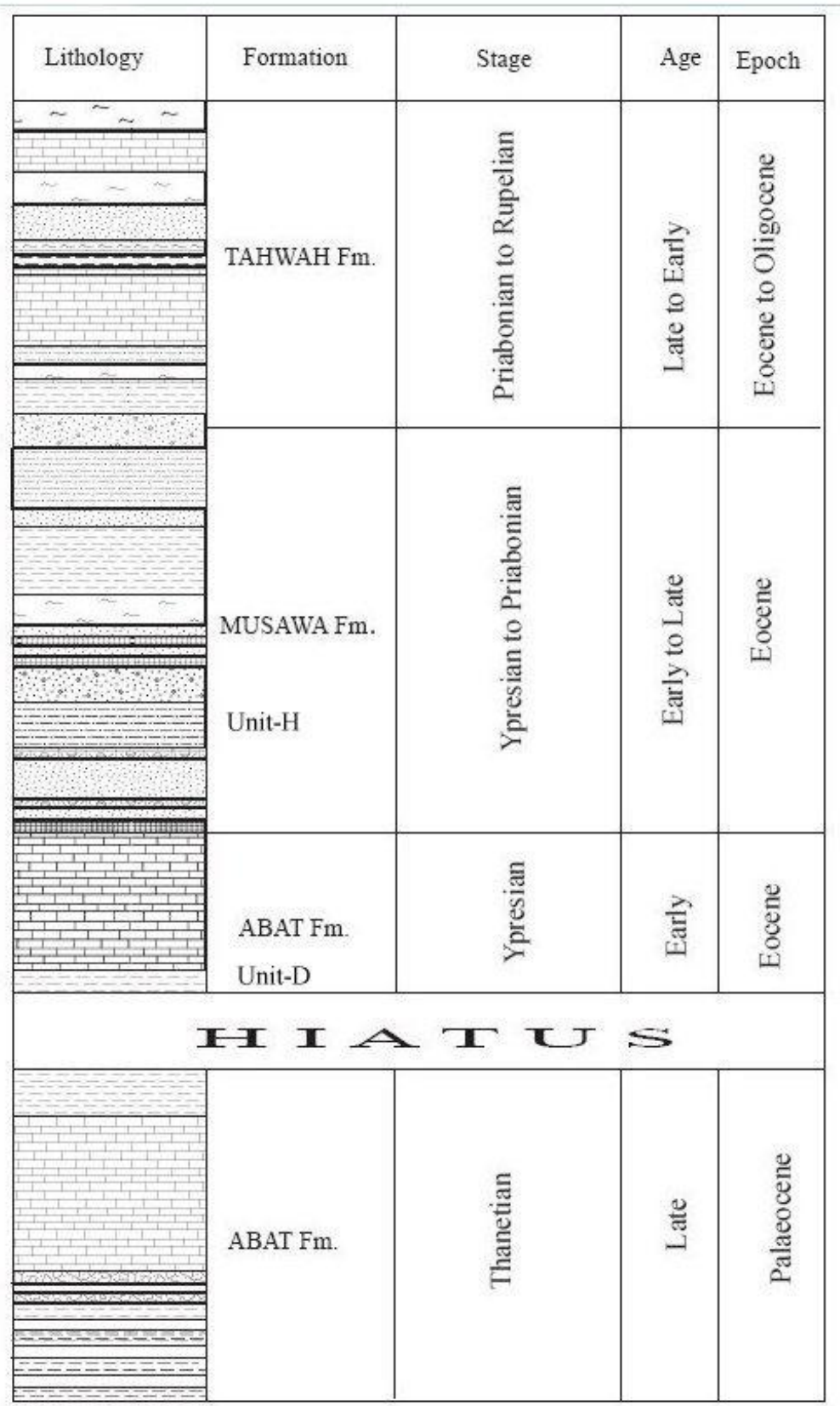

Figure 2. Lithostratigraphic column of the Wadi Musawa Section.

Planktonic foraminifera, including Morozovella sp. and Subbotina sp., are common in the mudstone and shale of the lower part of the formation. Larger foraminifera, including Discocyclina sp., Daviesina sp., Miscellanea sp., Nummulites sp. and Assilina sp. together with small rotaliids, textulariids, calcareous red algae, echinoids and corals are common in the limestone of the upper part of the Abat Formation (Figure 3). The larger foraminifera commonly appear to have been penecontemporaneously redeposited and become progressively more abraded up section. Reworked Cretaceous radiolaria and charophytes also occur within this interval.

The Abat Formation has been dated as Late Palaeocene to Early Eocene (Thanetian to Ypresian) on the basis of its planktonic foraminifera, and comprises a thick sequence of open-marine basinal sediments. Common deep-marine planktonic-foraminiferal shale and mudstone form the lower part of the Abat Formation which shoals upwards into high-energy middle to outer shelf limestone. The latter is dominated by larger and smaller benthonic foraminifera with subordinate dasycladacean algae, calcareous red algae, echinoid plates and corals. The specimens of Operculina musawaensis n. sp. described herein were collected from the lower part of Unit D of the Abat Formation (Figure 2). 
A.R.S. AL-SAYIGH

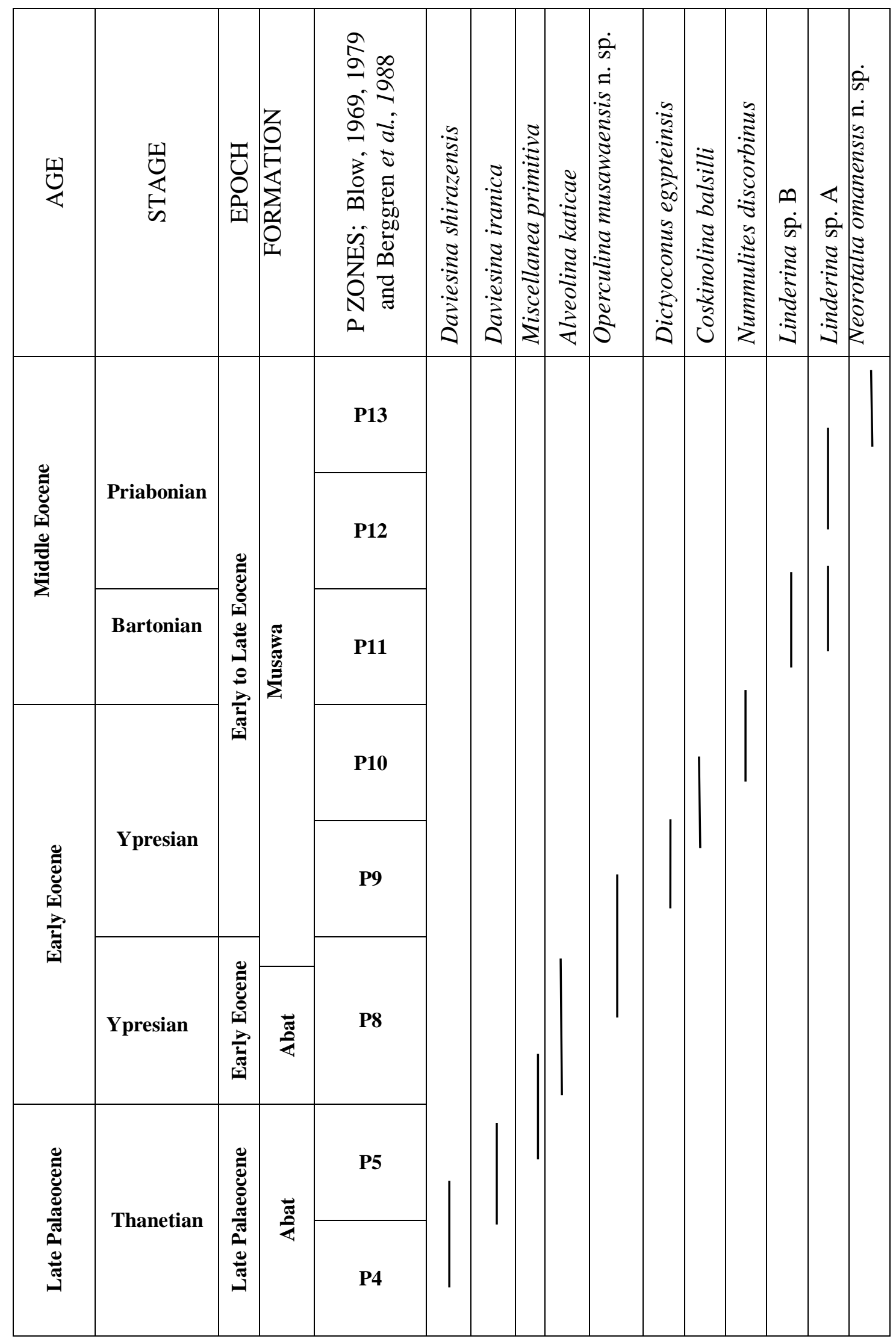

Figure 3. Distribution chart of the key taxa of benthonic foraminifera. 


\section{NEOROTALIA OMANENSIS and OPERCULINA MUSAWAENSIS}

\section{UNIT D}

Description: This unit begins with packstone and mudstone separated by a very thin $(7 \mathrm{~cm}$ thick) distinctive silicified mudstone from an overlying a $24 \mathrm{~m}$ thick massive larger foraminiferal limestone (wackestone-packstone). The basal part of Unit D comprises bioturbated limestone (packstone) overlain by mudstone rich in planktonic foraminifera (Acarinina sp. and Morozovella sp.) and larger foraminifera including Alveolina sp., Nummulites sp., Discocyclina sp. and Operculina musawaensis n. sp. This passes upwards into shale containing Nummulites and small rotaliids. The unit becomes more indurated up-section and rich in larger foraminifera, ostracods, corals, bivalves, gastropods and oysters. Lithoclasts and foraminifera are less abundant in the uppermost part of the unit, where clasts of grey chert are common, together with rare silicified burrows. Bivalves (often disarticulated) are also common in the uppermost part of the unit.

The characteristic microfossils in the Abat Formation include larger foraminifera (Alveolina sp., Nummulites honogoensis, N. globulus, Discocyclina sp., Assilina ex. gr. exponens, Somalina sp., Actinocyclina sp., Operculina musawaensis $n$. sp., Ranikothalia sp.) together with planktonic foraminifera (Acarinina esnaensis, A. soldadoensis and Morozovella aragonensis) which occur in the basal part of this unit. Other fossil fragments present include gastropods; and rare brachiopods, with smaller rotaliids, miliolids and textulariids. Rare dasycladacean algae occur in the middle to upper part of this unit, together with ostracods (Bairdia sp., Cytherella sp., Phalococythere sp. and Xestoleberis sp.). Age: An Early Eocene age is indicated by the presence of Morozovella marginodentata, M. aragonensis, Acarinina esnaensis, and A. soldadoensis along with associated larger foraminifera, including Nummulites cf. globulus. Although Somalina is typically considered to be Middle Eocene in age, White (1989) found Somalina hottingeri in late Early Eocene rocks from the northern Oman Mountains. This unit corresponds to the Morozovella aragonensis Zone (P8) of Blow (1969) and Berggren and Miller (1988).

Thickness: $33 \mathrm{~m}$.

Environment: The unit shows a gradual change from deep marine basinal facies rich in planktonic foraminifera in its lower part into shallow marine mid-outer shelf limestone with Nummulites sp., Assilina sp. and Discocyclina sp., and rare dasycladacean green algae (fragments) in its upper part. The Abat Formation is capped by non-fossiliferous shale of probable fluvial origin and palaeosols. Ostracods (Bairdia sp., Cytherella sp., Phalcocythere sp. and Xestoleberis sp.) suggest a shallow marine environment.

\section{Musawa Formation}

Type-Locality: Wadi Musawa - Latitude $22^{0} 19^{\prime} \mathrm{N}$ and Longitude $58^{0} 23^{\prime} \mathrm{E}$

The Early to Late Eocene (Ypresian to upper Bartonian) Musawa Formation comprises a regressive siliciclastic package at its base and a transgressive interval at its top. It contains fluvial sandstones, palaeosoland coal and shale, together with marine mudstone bearing planktonic foraminifera and re-deposited larger foraminifera and radiolaria. Reworked radiolaria and charophytes tend to occur together, especially in the fluviatile, coal-bearing beds. The middle part of the Musawa Formation represents an outer shelf environment.

The lower part of the Musawa Formation is characterised by deep, open marine planktonic foraminifera including Morozovella sp.. Its middle part is dominated by planktonic foraminifera ( $M$. edgari, Globigerinatheka sp., Truncorotaloides sp. and Turborotalia blowcentralis).

The upper part of the Musawa Formation represents a shallow marine, outer shelf environment with common insitu larger foraminifera including Nummulites sp., Operculina sp., Discocyclina sp., Dictyoconus sp., Coskinolina sp, and Neorotalia omanensis n. sp. Bivalves and gastropods, including Bicorbula sp., lucinids and naticids (N. Morris, 1998), are indicative of an intertidal to tidal-flat environment. The uppermost part of the formation consists of innershelf facies with miliolids and molluscs. It becomes more estuarine-dominated towards its top as indicated by the presence of coal seams and the presence of ostracods such as Neocyprideis sp., Bythocypris sp., Hornibrookella sp. and Paracosta sp. Neorotalia omanensis n. sp. and Linderina sp. specimens were collected from Unit $\mathrm{H}$ of the Musawa Formation.

\section{UNIT H}

Description: This unit consists of $75 \mathrm{~m}$ of marl overlain by 2-3 m of nodular grey limestone and marl. A three meter thick hummocky-cross-stratified limestone caps this unit. The marl layers contain abundant conical-shaped solitary corals and larger foraminifera, including Alveolina sp., Discocyclina dispansa, Nummulites sp., Neorotalia omanensis n. sp., miliolids and ostracods. The hummocky-cross-stratified limestone contains Bicorbula sp., lucinids and naticids.

Planktonic foraminifera. including Morozovella sp, Truncorotaloides libyaensis, and Globigerina sp., occur in the middle of the unit. The larger foraminifera include Nummulites maculatus, Nummulites cf. schaubi, Discocyclina dispansa, Assilina sp., Alveolina sp., Neorotalia omanensis n. sp., Operculina sp., Linderina sp., Nonionella sp., Pararotalia sp. and miliolids and rare ostracods. Burrows and macrofossils, including gastropods (i.e. Natica sp.), oysters and corals occur throughout.

Age: Middle Eocene (upper Lutetian) age is indicated by the presence of the planktonic foraminifera $\div$ Truncorotaloides libyaensis, Truncorotaloides topilensis, Morozovella bolivariana, Globigerinatheka barri, Globigerinatheka curryi and Globigerinatheka sp.. Benthonic foraminifera (Nummulites schaubi and N. maculates) were recorded by Racey (1995) from the Middle Eocene (lower and middle Lutetian) of the northern Oman Mountains. The unit ranges within the 


\title{
A.R.S. AL-SAYIGH
}

Truncorotaloides topilensis Zone to the Truncorotaloides libyaensis/Morozovella bolivariana Zone, representing the local expression of the standard zones, the Globigerinatheka subconglobata subconglobata Zone to the Orbulinoides beckmanni Zone (P13), of Blow (1969) and Berggren and Miller (1988).

Thickness: $81 \mathrm{~m}$

Environment: This is an outer shelf environment which was deeper at the base of the unit. It is indicated by abundant and diverse planktonic foraminifera. The topmost part of the unit is characterized by a low-intertidal to sub-tidal molluscan assemblage (N. Morris, Personal commun. 1998).

\author{
TAXONOMIC NOTES \\ SYSTEMATIC PALAEONTOLOGY \\ Order Foraminiferida (Eichwald, 1830) \\ Suborder Rotaliina, (Delage and Hérouard, 1896) \\ Superfamily Rotaliacea (Ehrenberg, 1839) \\ Family ROTALIIDAE (Ehrenberg, 1839) \\ Type species: Neorotalia mexicana Nuttall, 1928
}

Description: Test low trochospiral. The umbilicus is filled with a simple plug and the wall is finely pillared dorsally and ventrally. In equatorial section the chambers are high and narrow and the intercameral septa are strongly doubled peripherally only.

\section{Neorotalia omanensis Al-Sayigh n. sp. Plate 1, Figures 1-8}

Material: Twenty three specimens found in samples WME 148 and WME 184 (Unit H), from the Musawa Formation, Wadi Musawa Section, SE Oman. Latitude 22 $2^{\circ} 19^{\prime} 11^{\prime \prime} \mathrm{N}$ and Longitude 58 23' 10" E.

Type- specimens: Holotype Plate 1, Figures1-3, sample WME 184.

Paratypes Plate 2 , Figures 4-6, sample WME 148.

Depository: Earth Sciences Department, College of Science, Sultan Qaboos University, Muscat, Sultanate of Oman ARS - N1, ARS - N2 and ARS-N3 2005.

Etymology: After Sultanate of Oman Country.

Diagnosis: A distinctive large (2.3 mm diameter) planoconvex species of Neorotalia with 9-13 chambers in the last whorl. Surface coarse and pustulate, umbilical region characterised by a rosette pattern of plugs.

Description: Test trochoid, rounded planoconvex. Periphery lobate to subcircular. There are 3-3.5 whorls with 9-13 triangular chambers in the last whorl in the equatorial section. Umbilical side strongly convex with large pillars on the umbilical shoulder surrounded by fine pustules. Spiral side flat to slightly convex with pustules coarser towards centre. Aperture is extraumbilical-umbilical.

Dimensions: Holotype Diameter $2.3 \mathrm{~mm}$. thickness $1.3 \mathrm{~mm}$

Paratypes Diameter $2.2 \mathrm{~mm}$. thickness $1.1 \mathrm{~mm}$

Neorotalia omanensis n. sp. specimens are slightly different from Neorotalia aticantina, as described by Colom (1954), which is biconvex and smaller in size ( 0.5 to $0.7 \mathrm{~mm}$ in diameter and 0.4 to $0.6 \mathrm{~mm}$ thick). The Omani species have fine pustules at the periphery coarsening towards the centre on both sides, and a greater number of whorls than Neorotalia aticantina (Colom,1954) and Neorotalia mexicana (Nuttall, 1952). The N. omanensis shows a greater number of chambers in the last whorl than $N$. aticantina (Colom, 1954) and has an equal number of chambers in the last whorl to N. mexicana (Nuttall, 1952). The genus Neorotalia shows some similarities with Daviesina, although Daviesina is restricted to the Palaeocene and has a circular to subcircular, slightly trochospiral test with large pillars on umbilical shoulders.

Geographic distribution and stratigraphic range: The genus Neorotalia is previously unknown from the Middle East, having been reported from the Oligocene of southern Mexico (Nuttall, 1952) and the Ypresian/Lutetian boundary in Spain (Colom, 1954).

Local range and faunal associations: The Musawa Formation containing Truncorotaloides topilensis, Morozovella edgari and Globigerinatheka euganea, indicates a lower to middle Lutetian age. This species ranges from the Morozovella edgari/Truncorotaloides topilensis Zone (P10) to the Truncorotaloides libyaensis/Morozovella bolivariana Zone (P13), which is equivalent to the Hantkenina nuttalli Zone (P10) and to the Orbulinoides beckmanni Zone (P13) of Blow (1969) and Berggren and Miller (1988) respectively.

\section{Description}

Genus Operculina (d'Orbigny 1826)

Type species Lenticulites complanatus (Defrance, 1822)

Planispirally coiled, evolute with flat to flattened lenticular to compressed test; loosely coiled with rapidly opening spire, comprising few whorls and subdivided by numerous high chambers. Wall calcareous, perforate with smooth or pustulose surface. 

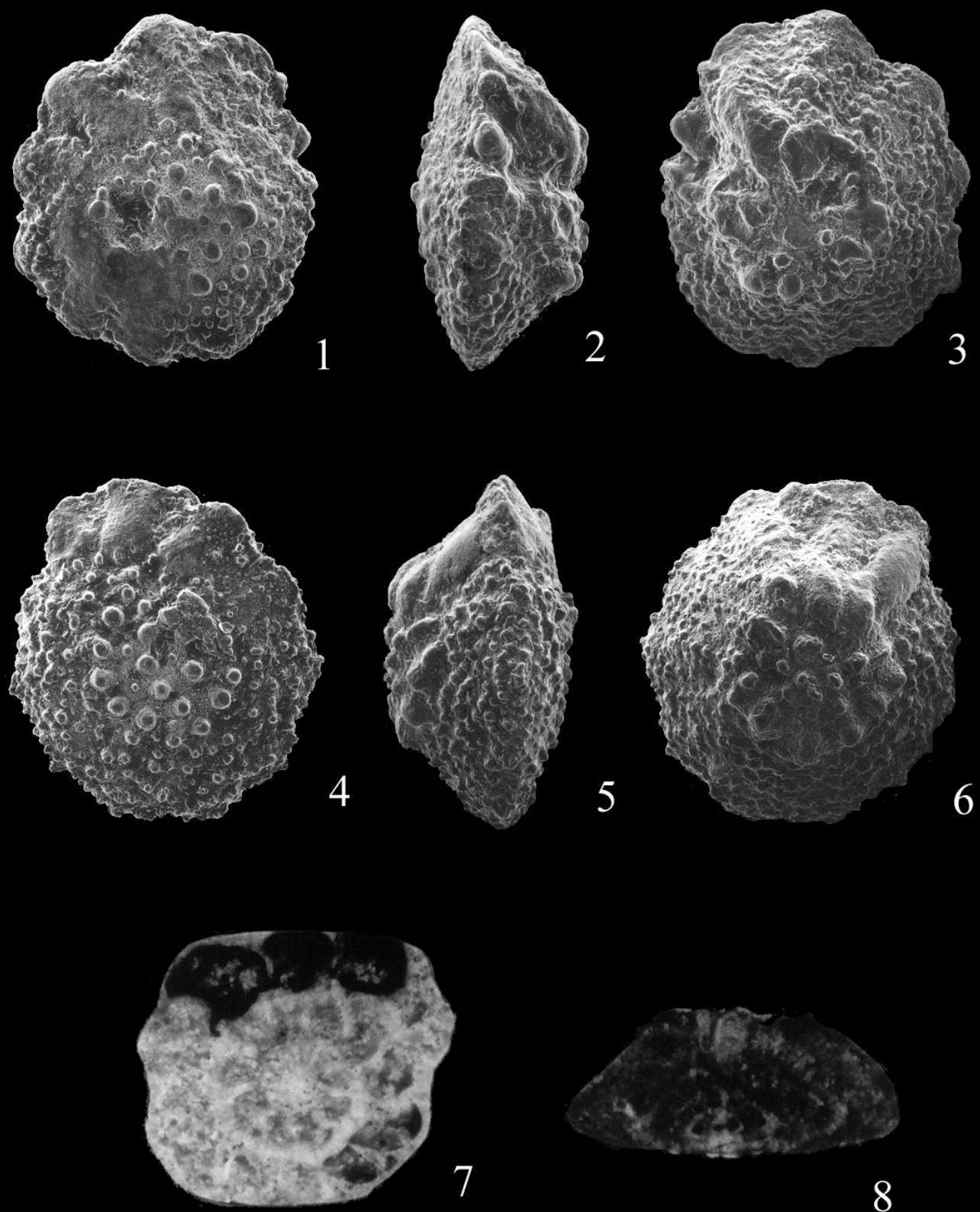

7

Plate 1:

Figures 1-6 Neorotalia omanensis n. sp. From samples WME 148 and WME 184, Wadi Musawa section, Jabal Ja'alan area, SE Oman. Middle Eocene. in spiral, edge and umbilical view, respectively, x65. Figures 1-3 Holotype Figures 4-6 Paratype.

Figures 7-8 Neorotalia omanensis n. sp. paratypes from sample WME148, Wadi Musawa section, Jabal Ja'alan area, SE Oman. Middle Eocene. Equatorial and axial sections, x50 and x55 respectively. 


\section{A.R.S. AL-SAYIGH}

Operculina musawaensis Al-Sayigh $n$. sp.

Plate 2, Figures 5-8

Material: 12 specimens of A-forms from sample WM35, Abat Formation (Unit D), Wadi Musawa. GRID REFERENCE Lat. $22^{\circ} 19^{\prime} \mathrm{N}$ and Long. $58^{0} 23^{\prime} \mathrm{E}$.

Type species: Holotype: Plate 2. Figure 4

Paratypes: Plate 2. Figures 6-8

Depository: Earth Sciences Department, College of Science, Sultan Qaboos University, Muscat, Sultanate of Oman. ARS - O1, ARS - O2 and ARS - O3. 2005.

Etymology: After Wadi Musawa, SE Oman Mountains, Sultanate of Oman Country.

Diagnosis: A small heavily pustular species with a distinctive large polar pustule, relatively few chambers per whorl and a markedly tight spire (4 whorls in a radius of about $1 \mathrm{~mm}$ ).

Description:

A-form. Test discoidal, flat with polar region thickened by secondary lamellation. Marginal cord is well-developed with septal sutures radial and recurved towards the periphery. Chambers are 1.5-2 times higher than wide with twenty four arcuate chambers in the last whorl. The spire is tight and opens uniformly. The proloculus has an internal diameter of $0.035-0.043 \mathrm{~mm}$.

\section{Dimensions}

$\begin{array}{lccc} & \text { Maximum } & \text { Minimum } & \text { Average } \\ \text { Diameter }(\mathrm{mm}) & 1.7 & 1.6 & 1.65 \\ \text { Height }(\mathrm{mm}) & 0.22 & 0.17 & 0.19 \\ \text { D/T } & 7.7 & 16 & 8.68\end{array}$

\begin{tabular}{|l|l|l|l|l|}
\hline Whorl \# & 1 & 2 & 3 & 4 \\
\hline Radius (mm) & $0.15-0.17$ & $0.24-0.35$ & $0.56-0.64$ & 1.01 \\
\hline $\begin{array}{l}\text { Chambers } \\
\text { Number }\end{array}$ & $7-8$ & $11-16$ & $17-19$ & $22-25$ \\
\hline
\end{tabular}

\section{A-form (Paratype)}

\section{B-Form}

Not found

Remarks: This species is similar to Operculina campi, described by Graham (1950) from the Miocene Meganos Formation of California, but differs in possessing more whorls (6-7 whorls in $O$. campi) and has a flatter, more compressed test. $O$. campi is known only from the Miocene. O. musawaensis also differs from $O$. jiwani, described by Racey (1995) from the late Palaeocene of Oman, in that $O$. jiwani has a larger test diameter $(1.26-2.37 \mathrm{~mm})$ and a larger proloculus (0.063-0.094 mm).

Geographical distribution and stratigraphic range: Previously unknown.

Local range and faunal associations: Found in Wadi Musawa in the Abat Formation in association with Acarinina esnaensis and A. soldadoensis within the Acarinina soldadoensis Zone (P6) indicating an Early Eocene age. Other associated larger foraminifera are Alveolina sp., Nummulites honogoensis, N. globulus, Discocyclina sp., Assilina ex. gr. exponens, Somalina sp., Actinocyclina sp., Operculina musawaensis n. sp. Associated planktonic foraminifera are Morozovella aragonensis and Subbotina quadrata.

Family: LINDERINIDAE Loeblich and Tappan, 1964

Genus Linderina Schlumberger, 1893

Type species: Linderina brugesi Schlumberger, 1893

\section{Generic description of Linderina}

Test large up to $3.5 \mathrm{~mm}$ in diameter, discoidal, centrally thickened. Periphery rounded, peripheral outline lobate, wall calcareous and test surface covered with small pustules. Early chambers of microspheric test form an irregular cluster, rather than a distinct spire. Megalospheric test with bilocular embryo followed by a nepionic ring of seven to eight small chambers with a concentric series of small arched chambers in a single equatorial layer. Younger chambers are progressively larger and alternating in position. Early stage is covered by numerous layers of calcite resulting in an inflated central region traversed by fine pores connecting the chambers to the exterior. Apertures and intercameral openings occur at the base of the chamber against the chambers of the previous whorl. 


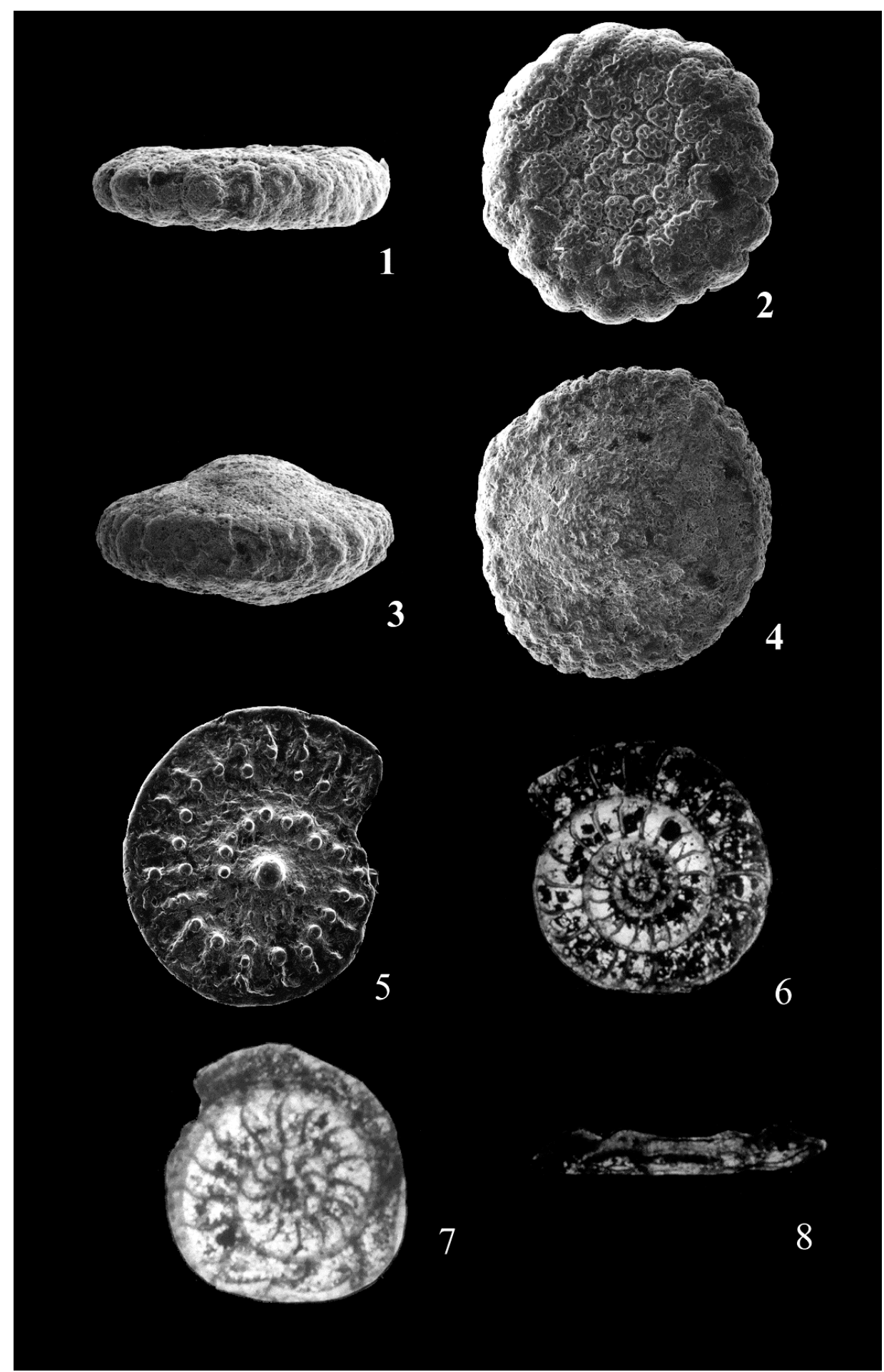

Plate 2:

Figures 1-2 Linderina sp. A. From sample WME 184, Wadi Musawa section, Jabal Ja'alan area, SE Oman. Middle Eocene. Edge and side view, respectively, x50.

Figures 3-4 Linderina sp B. From sample WME 148, Wadi Musawa section, Jabal Ja'alan area, SE Oman. Middle Eocene. Edge and side view, respectively, x20.

Figures 5-8 Operculina musawaensis n. sp. Holotype (A-form). From sample WM 35 Wadi Musawa section, Jabal Ja'alan area, SE Oman. early Eocene. Side view, x30.

Figures 7-8 Operculina musawaensis n. sp. paratypes A-forms from sample WM 35, Wadi Musawa section, Jabal Ja'alan area, SE Oman. early Eocene. equatorial oblique and axial section, respectively, all x30. 

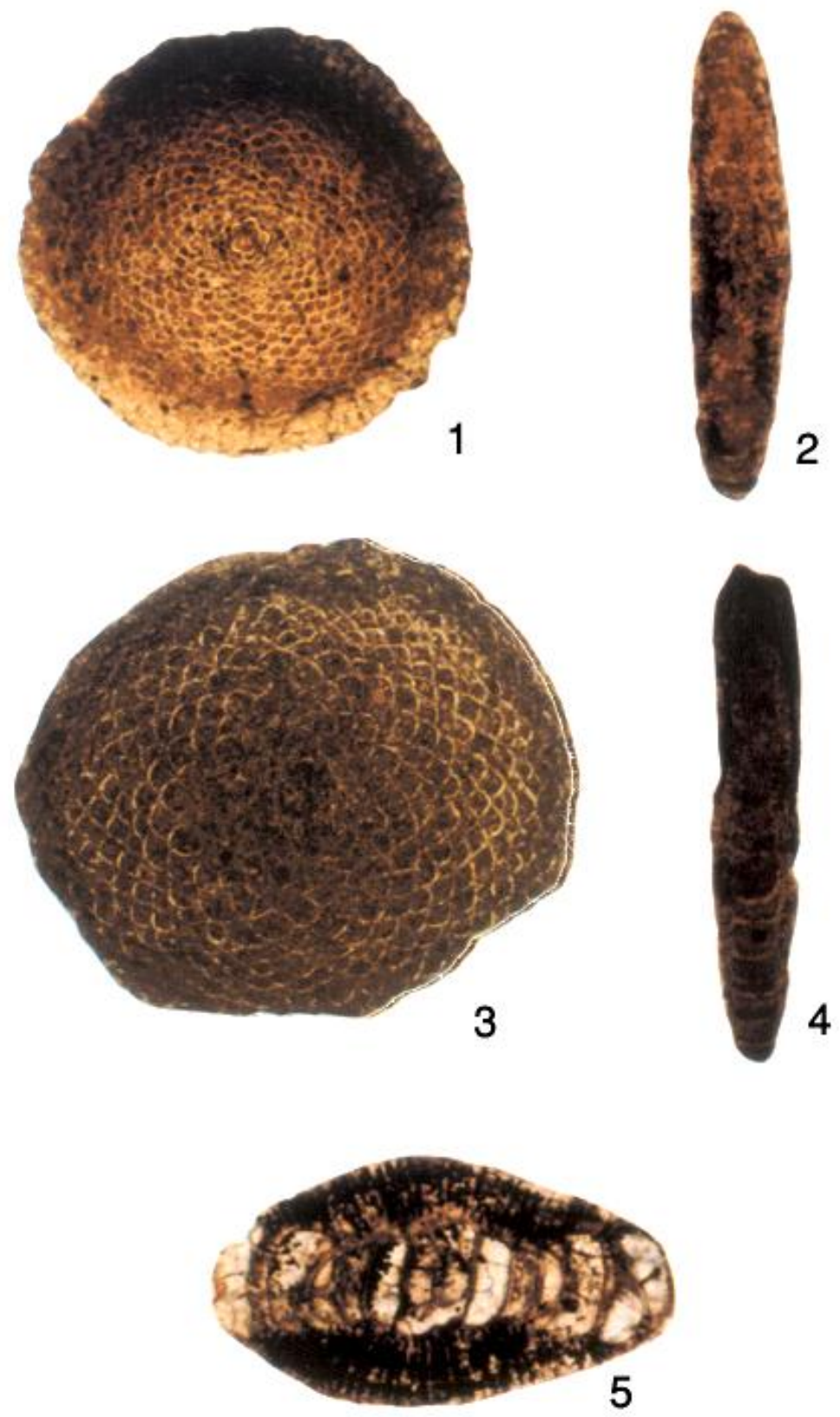

Plate 3:

Figures 1-4 Linderina sp. A

Figure 5 Linderina sp. B

\section{Discussion}

Illustrations in the Ellis and Messina Catalogue (1940) and observations during this study suggest that the globular forms with umbonal lamellar thickening (e.g. Plate 2, Figures 3-4; Plate 3. Figure 5) are all megalospheric, whereas the discoidal forms (without or with very little umbonal lamellar thickening e.g. Plate 2, Figures 1-2, Plate 3, Figures 1-4) appear to be microspheric.

Of the sixteen published species, four are now assigned to other genera: Linderina douivillei (Silvestri, 1948) to Orbitoides (Neumann, 1958); L. visserae (Hofker, 1958) to Hellenocyclina (MacGillavry, 1963); L. ovata (Halkyard, 


\section{NEOROTALIA OMANENSIS and OPERCULINA MUSAWAENSIS}

1919) to Droogerinella (Popescu and Brotea, 1994) and L. chapmani (Halkyard, 1919) to Halkyardia (Neumann, 1958). Of the remaining potentially valid species L. rajasthanensis (Singh, 1953), L. kirtharensis (Singh, 1953$), L$. kolayatensis (Singh, 1953), L, bikanerensis (Singh, 1953), L. paronai, Osimo, L. floridensis (Colom,1954), and L. bihilensis (Silvestri, 1948) are known only from megalospheric forms and pustules. L. nuttalli is known only from a microspheric form. Two species, L. brugesi (Schlumberger, 1893) and L. buranensis (Nuttal and Brighton,1930) are known from megalospheric and microspheric forms. All records appear to be from the Middle Eocene to the lower part of the Upper Eocene (Bartonian).

Freudenthal (1969) further reduced these ten species to four: L. buranensis (within which he synonmised $L$. bihilensis and L. nuttalli), L. rajasthanensis (within which he synonymised L. bikanerensis, L. koyaltensis and $L$. kirtharensis), L. paranoi and L. floridensis. Freudenthal (1969) also mentioned that L. floridensis may be a synonym of $L$. paranoi.

This study refers to the globular form as sp. A and the discoidal form as sp. B.

Linderina sp. A

Plate 2, Figures 1-2, Plate 3, Figures 1-4

Material: Fourteen specimens from WME 181 and WME 183 from the Wadi Musawa section.

Description: Test small, biconvex, globular, stout with rounded periphery. Central pillars are absent. The protoconch is circular in outline and the deuteroconch is crescentic. Chambers in axial section are narrower at the center and increase gradually in thickness from the centre towards the periphery. Wall finely perforated. The proloculus size varies between 0.04 and $0.07 \mathrm{~mm}$ in diameter.

\section{Dimensions}

$\begin{array}{llcc} & \text { Maximum } & \text { Minimum } & \text { Average } \\ \text { Diameter }(\mathrm{mm}) & 1.40 & 1.02 & 1.21 \\ \text { Height }(\mathrm{mm}) & 0.81 & 0.49 & 0.65 \\ \text { D/T ratio } & 1.73 & 2.08 & 2.28\end{array}$

Remarks: This species differs from Linderina bikanerensis Singh (1953) in having a larger and more globular test and circular protoconch, and can thus be distinguished externally and internally.

Geographic distribution and stratigraphic range: Previously known from the Middle East under a variety of names. The genus Linderina is also known from the upper chocolate clay of Sulieman Range, Pakistan (Adams, 1970) and from Rajistan, India (Singh, 1953) and Meghalaya (Nagapa, 1956).

Local range and faunal associations: Linderina sp. A is found at Wadi Musawa in association with Globigerinatheka barri in strata of presumed Middle Eocene age, within Truncorotaloides topilensis Zone P11 and Globigerinatheka barri Zone, which is equivalent to Globigerinatheka subconglobata subconglobata and Morozovella lehneri Zones (P11-P12) of Blow (1969) and Berggren and Miller (1988). The associated fauna includes: the planktonic foraminifera Truncorotaloides libyaensis, Morozovella bolivariana, Globigerinatheka barri, Globigerinatheka curryi, Globigerinatheka sp. benthonic foraminifera Nummulites schaubi and N. maculatus were recorded by Racey (1995).

Linderina sp. B.

Plate 2, Figures 3-4, Plate 3, Figure 5

Material: Twenty five specimens from sample WME 182.

Description: Test large, discoidal with rim encircling the central area and with a slightly wavy periphery. Equatorial chambers arcuate, large and arranged overlapping alternately, increasing in size towards the center varying in size from $0.09 \mathrm{~mm}$ to $0.12 \mathrm{~mm}$ across. In axial section the test is thick at the centre and narrows towards the margins. Pillars are fine, radial over most of the test. Protoconch is about $0.11 \mathrm{~mm}$ in axial section, and $0.08 \mathrm{~mm}$ in equatorial section.

\section{Dimensions}

$\begin{array}{lccc} & \text { Maximum } & \text { Minimum } & \text { Average } \\ \text { Diameter }(\mathrm{mm}) & 2.2 & 1.5 & 1.85 \\ \text { Height }(\mathrm{mm}) & 0.33 & 0.29 & 0.31 \\ \text { D/T ratio } & 6.66 & 5.17 & 5.97\end{array}$

Remarks: This species is characterized by its discoidal test, wavy test periphery and distinctive equatorial chambers. Geographic distribution and stratigraphic range: Previously known from the Middle East.

Local range and faunal associations: Linderina sp. B is found in Wadi Musawa in association with Truncorotaloides topilensis and Morozovella sp., indicating a Middle Eocene age within the Truncorotaloides topilensis Zone (P11), equivalent to the Globigerinatheka subconglobata subconglobata Zone (P11) of Blow (1969) and of Berggren and 


\section{A.R.S. AL-SAYIGH}

Miller (1988). Associated larger foraminifera include Alveolina sp., Discocyclina dispansa, Nummulites and Neorotalia omanensis $\mathrm{n} . \mathrm{sp}$.

\section{Conclusions}

Two new larger foraminiferal species, Operculina musawaensis n. sp., and Neorotalia omanensis n. sp., are described and illustrated. The presence of Neorotalia sp. represents the first record in the Middle East. Two forms of Linderina sp. are also described and illustrated. It is concluded that of the sixteen published species, four ( $L$. douvillei, L. visserae, L. ovata and L.chapmani) are referable to other genera and one ( $L$. baldaci) is insufficiently described/illustrated to permit even a generic assignment. Of the remaining species, two are known from both megalospheric and microspheric specimens (L. brugesi and L. buranensis), one is only known from a microspheric form ( $L$. nuttalli) and the remainder are only known from megalospheric forms (L. bikinarensis, L. floridensis, $L$. glaesseneri, L. kirtharensis, L. kolayatensis, L. paronai, and L. rajahstanensis). Of these, L. kolyatensis, $L$. bikanerensis L. kirtharensis and L. rajahstanensis are synonymous (with L. rajahstanensis having priority) and the status of L. glaessneri remains problematic. Closer examination of the Oman materials and published descriptions indicate that globular forms with umbonal lamellar thickening are megalospheric and discoidal forms without or with very little umbonal lamellar thickening are probably microspheric. Because test size and shape (both dependent to a certain degree on the amount of lamellar thickening) are not species specific, many of the Linderina species could be grouped under a single species. Alternatively, the smaller globular forms may be juveniles.

\section{Acknowledgements}

The author thanks Haynes, J.R. (University of Wales), Whittaker, J.E. (Natural History Museum, London), Nasir, S. and Hanna, S. (Sultan Qaboos University) for their support.

\section{References}

ADAMS, 1970. A reconsideration of the East Indian Letter Classification. Bulletin of the British Museum (Natural History) Geology, 19:(3)1-13

BERGGREN, W.A. and MILLER, K.G. 1988. Paleogene tropical planktonic foraminiferal biostratigraphy and magnetobiochronology. Micropaleontology, 34(4): 362-380.

BLOW, W.H. 1969. Late middle Eocene to Recent planktonic foraminiferal biostratigraphy. In: Bronnimann, P. and Renz, H.H. (Eds.) Proceedings of the First International Conference on Planktonic Microfossils, Geneva. 1: 199422. E.J. Brill, Leiden.

COLOM, G. 1954. Estudio de las biozonas con Foraminiferos del Terciario de Alicante, Espana. Boletín, Instituto Geologico y Minero, 6: 1-279.

DELAGE, Y. and HÉROUARD, E. 1896. Lower Aptian shallow water foraminiferal assemblages. Traité de Zoologe Concrete, Vol. 1, La Cellule et les Protozoaires. . Pris: Schleicher Fréres.

DEFRANCE, M.L. 1822. Dictionnaire des sciences naturelles. Minèralogie et Géologie, 25. Levrault, Paris.

D’ORBIGNY, A. 1826. Tableau, methodiane, de, la xlasse des cephalopoes: Am. Sci: Nat., 7: 245-314.

EHRENBERG, C.G. 1839. Uber die Bildung der Kreidefelsen und des Kreidemergels durch unsichtbare Organsmen. Physikalische Abh. Kgl. Akad. Wiss. Berlin, 59-147.

EICHWALD, C.E. VON. 1830. Expositis Animalibus tum vivis, tum. Zoologia specialis, 2, Velnae: D. E. Eichwaldus, $1-323$.

ELLIS, B.F. and MESSINA, A.R. 1940. Catalogue of Foraminifera. American Museum of Natural History. (+ supplements).

FERRANDEX-CANADELL, C. and SERRA KIEL, J. 1999. Morphostructure and systematics of Linderina brugesi Schlumberger, 1893 (Foraminifera, Eocene), Geobios, 32(4): 529-537.

FILBRANDT, J.B., NOLAN, S.C. and RIES, A.C. 1990. Late Cretaceous and Tertiary evolution of Jabal J a'alan and adjacent areas, N E Oman. In: ROBERTSON, A.H.F., SEARLE, M.P. and RIES, C. (Eds.) The Geology and Tectonics of the Oman Region. Special Publications of the Geological Society of London, 49: 697- 714.

FREUDENTHAL, T. 1969. Stratigraphy of Neogene deposits in the Khania Province, Crete, with special reference to foraminifera of the family Planorbulinidae and the genus Heterostegina. Utrecht Micropaleontological Bulletin 1: 1-208.

GRAHAM, J.J. 1950. New foraminifera from the type Meganos Formation (Eocene) of California. J. Paleontology, 24: 282-304.

HALKYARD, E. 1919. The fossil Foraminifera of the blue Marl of the cote des. Basques, Biarritz. Edited with additions by HERON-AFTER, E. and EARLAND MEM, A. Proc. Manchaster Lit. Phil Soc. 62: 1-145.

HOFKER, J. 1958 Faraminifera from the cretaceous of Limburg, Netherlands, Linderina, visserae nov. se Natuurhistorisch, maandblad 47: 125-127. 


\section{NEOROTALIA OMANENSIS and OPERCULINA MUSAWAENSIS}

LOEBLICH, A.R.Jr. and TAPPAN, H. 1964. Sarcodina, chiefly "Thecamoebian': and Foraminiferida. In: MOORE, R.C. (Ed.), Treatise on Invertebrate aleontology, Part C, Protista 2.2: pp. 511-900. Geological Society of America and University of Kansas Press.

MacGILLAVRY, H.J. 1963. Phylomorphogenesis and evolutionary trends of Cretaceous orbitoidal foraminifera. In : KOENIGSWALD, G.H.R. VON, EMEIS, J.D., BUNING, W.L. and WAGNER, C.W. (Eds.) Evolutionary Trends in Foraminifera. Elsevier Publishing Company, Amsterdam-London-New York 139-197.

MONTENAT, C., BLONDEAU, A., BIZON, G., PEFFEAU, M., RAJU, D.S.N. and ROMAN, J. 1977. Premier apercu du Tertiare d'Oman (Peninsule arabique orientale). Bulletin de la Societe Geologique de France, 19: 1285-1295.

MORRIS, N. 1998. Personal commun, British Natural History Museuum. London.

NAGAPA, Y. 1956. Foraminifera of the genera Fabiano and Eorupertia from the Sylnet Limestone of Assam. $J$. Paleontit. Soc. Ndd. 1: 191-198.

NEUMANN, M. 1958. Revision des Orbitoidides du cretace et de Eocene en Aquilaine accidentale Memories de la Societe geologique de France, 83: 174.

NUTTALL, W.L.F. 1928. Notes on the Tertiary foraminifera of southern Mexico. J. Paleontology, 2: 372-376.

NUTTALL, W.L.F. and BRIGHTON, A.G. 1931. Larger foraminifera from the Tertiary of Somaliland. Geological Magazine, 68: 49-65.

NUTTALL, W.L.F. 1952 on the Upper Cretaceous and Lower Tertiary unicrofaunas of Israel. Israel, Res, Council, Bult., 2: 37-50.

POPESCU, Gh. and BROTEA, D. 1994. Evolution of the Transylvanian foraminiferal assemblages during Late Oligocene and Middle Miocene. In: NICORICI, E., BEDELEAN, I., MÉSZÁROS, N. and PETRESCU, I. (Eds.), The Miocene from the Transylvaniann Basin, Romania. Geological Formations of Transylvania, Romania 4, Cluj-Napoca, Romania, 119-124.

RACEY, A. 1995. Lithostratigraphy and larger foraminiferal (nummulitid) biostratigraphy of the Tertiary of northern Oman. Micropaleontology, 41: 1-123.

ROGER, J., BÉCHENNEC, F., JANOU, D., LE MÉTOUR, J., WYNS, R. and BEURRIÉR, M. 1991. Geological map of Ja'alan, sheet NF40-08E, Scale 1:100,000 with explanatory Notes. Directorate General of Minerals, Oman. Ministry of Petroleum and Minerals.

SCHLUMBERGER. C.M. 1893. Note sur les genres Trilling et Linderina. Bulletin la societe geologique de France, 3: $118-123$

SILVESTRI, A. 1948- Foraminifei dell, Eocene della Somalia, Parte III, 2 Palaeontographia Italica, 32(6): $277-331$.

SINGH, S.N. 1953 - Species of the genus Linderina from the Kirthars of Kolayat, Bikaner, India. Proceedings of the Natural Academy of Sciences, India, 23: 21-28.

VILLEY, M., LE METOUR, J. and DE GARMENT, X. 1986. Geological Map of Fanjah, Sheet AT 40-03F, with Explanatory notes. Bureau de Recherches Geologiques et Minieres, Orleans (for the Ministry of Petroleum and Minerals, Sultanate of Oman).

WHITE, M.R. 1989. A new species of Somalina (Somalina hottingeri) with partially vacuolate lateral walls from the Middle Eocene of Oman. J. Micropalaeontology, 16: 131-135.

Received 13 February 2013

Accepted 30 October 2013 